\title{
John Maynard Smith's typology of animal signals: A view from semiotics
}

\author{
Timo Maran \\ Department of Semiotics, Institute of Philosophy and Semiotics, University of Tartu \\ Tiigi 78, Tartu 50410, Estonia \\ e-mail: timo.maran@ut.ee
}

\begin{abstract}
Approaches to animal communication have for the most part been quite different in semiotics and evolutionary biology. In this context the writings of a leading evolutionary biologist who has also been attracted to semiotics - John Maynard Smith - are an interesting exception and object of study. The present article focuses on the use and adaptation of semiotic terminology in Maynard Smith's works with reference to general theoretical premises both in semiotics and evolutionary biology. In developing a typology of animal signals, Maynard Smith employs the concepts of icon, index and symbol to denote distinct signal classes. He uses "indices" or "indexes" to express a signal type where the relation between signal properties and meaning is restricted because of physical characteristics. Such approach also points out the issue of the motivatedness of signs, which has had a long history in semiotics. In the final part of the article the usage and content of the concepts of signal form and meaning in Maynard Smith's writings are analysed. It appears that in evolutionary biology, the "signal" is a vague concept that may denote a variety of things from an animal's specific physiological status to artificial theoretical constructs. It also becomes evident that in actual usage the concept of signal often includes references to the receiver's activity and interpretation, which belong rather to the characteristics of sign process. The positive influence of Maynard Smith's works on semiotics could lie in paying attention to the role of physical necessities in animal communication. Physical constraints and relations also seem to have a significant role in semiotic processes although this is not always sufficiently studied or understood in semiotics.
\end{abstract}


An appreciation of semiotics by an evolutionary biologist is a rare event that certainly deserves attention. Especially if the biologist under consideration is John Maynard Smith (1920-2004), a promoter of neo-Darwinian evolutionary biology and an author of well-known textbooks in animal communication (Maynard Smith, Szathmáry 2000; Maynard Smith, Harper 2003). There have been several attempts to establish a common ground between semiotics and animal communication studies, the most significant of those being perhaps the zoosemiotic research paradigm by Thomas A. Sebeok (1972, 1990), Peter Marler's semiotically accentuated studies in animal communication (for example, Marler 1961, Marler 1978) and Kalevi Kull's historical analyses on semiotic perspectives in biology (Kull 1999, Kull 2004). Some later efforts to build a bridge are also worth mentioning, such as Winfried Nöth's lucid overview Semiotics for biologists (Nöth 2005) and Thomas P. Weber's remark in Trends in Ecology and Evolution on the benefit of the semiotic approach for raising hypotheses in evolutionary biology (Weber 2000).

In this short survey, I am focusing on the explicit references to semiotics and their context in John Maynard Smith's writings and leave the rest of his vast legacy untouched. This means I do not include his position in debates on memetics, which is generally supportive (Maynard Smith 1995; Maynard Smith, Szathmáry 2000: 139-140), and his thoughts on the evolution of human language, which appear to be allied to biological determinism (Maynard Smith, Harper 2003: 133-136; Maynard Smith, Szathmáry 2000: 149-170). Concerning the proximity to semiotics, there are several relevant texts of interest by Maynard Smith (Maynard Smith, Harper 1995, 2003; Maynard Smith 1982, 1999, 2000). Although many of these are coauthored, contemplations that include references to semiotics have also been presented by Maynard Smith solely, which justifies regarding these as a part of his original heritage. On the other hand, many ideas and inclinations that I critically discuss in this article belong to the general legacy of evolutionary biology and their appearan- 
ce in Maynard Smith's writings should be treated as an individual occurrence of much wider development. Maynard Smith's texts relate to semiotics both in regard to terminology used (icon, index, symbol, arbitrariness, form, meaning, content, etc.) and references made (Charles S. Peirce, Umberto Eco). Maynard Smith's interest in semiotics has also been widely noted (for example, Szathmáry 2006, Williams 2007). There exists at least one study close to the topic of the present article, namely the analysis of the semantic content of the concept "animal signal" in Maynard Smith's writings with the reference to Ruth Millikan's teleosemantic theory (Stegmann 2005). I also touch upon the issue of meaning and the use of concepts of animal communication in Maynard Smith's writings in the second part of this article, but my approach and frame of analysis remain strictly semiotic (meaning zoo- and biosemiotics here and hereafter).

\section{Context of John Maynard Smith's writings in animal communication}

Despite his use of semiotic terminology and references, the context of Maynard Smith's interest is very different from that of semiotics. Namely, his aim in the considered publications is to establish and elaborate a typology of animal communication for evolutionary biology. Maynard Smith's approach is close to the gene-centric views of Richard Dawkins and understandings of communication by Mark D. Hauser, John R. Krebs, Oren Hasson and other eminent Neo-Darwinian evolutionary biologists. An essential problem concerning communication in this paradigm is the question of the reliability of the communication system. In evolutionary biology organisms are considered to be essentially egoistic (as maximising their fitness in evolution) and because of that they are believed to have generally conflicting interests in communication. This understanding was expressed by Richard Dawkins and John R. Krebs as conflict between 
senders as manipulators and receivers as mind-readers (Krebs, Dawkins 1984: 380-402) and it is also immanent in their (as well as in many other evolutionary biologists') definition of communication: "The process in which actors use specially designed signals or displays to modify the behaviour of reactors" (Krebs, Davies 1993: 349).

Built on this premise, a central question for evolutionary biology is: how does a communication system not become corrupt in evolution under the conflicting influences of its participants? One hypothesis, promoted by Israeli biologists Amotz and Avishag Zahavi under the name of the "handicap principle", argues that signals in honest communication must be costly to produce and maintain by the sender (have excess energetic cost) in the way that the same signals cannot be afforded by low quality individuals (Zahavi, Zahavi 1997: xv; Maynard Smith, Harper 1995: 306). This means that the handicap signals are superfluous and hindering, tail of the peacock being a textbook example. In Animal Signals: Models and Terminology John Maynard Smith and David Harper (1995) present their views on this question in the form of a three-dimensional typology of animal communication. The first distinction is made between types of information that signals convey (self-reporting signals, other-reporting signals and cues); the second classification describes the mechanism that is used to ensure the reliability of the signal (minimal signals, cost-added signals and indexes); and the third dimension describes the relationships between the signal form and the object of the signal (the semiotic terminology employed for this is discussed in the next chapter). The most remarkable aspect in this typology is perhaps the introduction of "indices" or "indexes" (the terms are used interchangeably), as a type of signals that by definition cannot be faked (Maynard Smith, Harper 2003: 45-67). Maynard Smith describes “indices" or "indexes" as reliable because of their motivatedness, that is, there exists a restrictive relation between the signal properties and the quality of the sender because of physical necessity (Maynard Smith, Harper 1995: 306). In addition to that, there are also other possible ways for a commu- 
nication system to remain functional such as inclusion of coordination games, where the sender and receiver prefer different outcomes, but share some overriding common interest; repeated interactions, where honest signalling contributes to the sender's reputation in the group; and behavioural punishment by species-mates for the sender of a false signal (Maynard Smith, Harper 2003: 30).

Although the question of the existence of a communication system under interest conflict can be a fascinating topic for semiotics, the validity of the presumption by Richard Dawkins, John R. Krebs and others about the manipulatory and deterministic nature of communication needs to be disputed. The well-established criticism against such position is presented by theoretical ethologist W. John Smith. He disproves the neo-Darwinian understanding of communication on the following grounds: 1) the emphasis is placed mostly on formalised signalling, while other sources of information for the receiver are not addressed; 2) formalised displays are not taken as probabilistic but rather believed to have one-to-one correspondence with the sender's subsequent behaviour; 3) the conditional nature of animal signals is not considered (for example, the receiver's ability to synthesise different types of information, send feedback to the sender, make predictions about future scenarios and act accordingly); and 4) the social environment where communication takes place is generally neglected (that is, long-term consequences of deceptive communication are not taken into account) (Smith 1986).

The general difference between the views of Smith and Maynard Smith (and many other neo-Darwinians) appears to lie in their understanding of the role of the sender and the receiver in communication. For Maynard Smith the sender is the one who controls the communicative situation whereas the receiver is a passive recipient. For Smith, on the contrary, it is the receiver who has autonomy and subjectivity of acting and who can relate different types of information (this position is also supported by many semioticians, c.f. Kull 2004: 103). For Smith the outcome of communication is undetermined and 
probable; for Maynard Smith it is rather determined and rigidly structured. The position taken by Maynard Smith appears to be inevitable for neo-Darwinian biology for demonstrating that the evolutionary success of different genes is the relevant factor for the outcome of animal communication. Giving an ability of choice for the receiver (as it is more often in animal psychology and especially prevalent in cognitive ethology) would make the situation too unpredictable for a reductionist paradigm.

This general understanding of communication is also perhaps grounds for an otherwise rather peculiar distinction made between signal and cue in Maynard Smith's writings. The signal is described as a tool of manipulation, as "an act or structure that alters the behaviour of another organism, which evolved because of that effect, and which is effective because the receiver's response has also evolved" (Maynard Smith, Harper 2003: 15), and the cue as "a feature of the world, animate or inanimate that can be used by an animal as a guide to future action" (Maynard Smith, Harper 2003: 15). Although the distinction itself appears to be fruitful, it is remarkable that the receiving organism is supplied with some interpreting skills in the case of cues, but the same is not included in the case of signals. From a semiotic perspective it is hard to perceive any communicative process as taking place without an organism's interpretive activity. A reason for the different use of the concept of cue lays perhaps in its Uexküllian origin. From the position of semiotics the differentiation could be regarded as a difference in the dynamic balance between the properties of message and interpretation, rather than a distinction between types of signs. At the same time it needs to be mentioned that on similar grounds, a distinction between signal and symptom has been made by Thomas A. Sebeok (1994: 22-28). 


\section{Employing icon, index and symbol with reference to motivatedness}

Another peculiar metamorphosis takes place when the semiotic notions of icon, index and symbol are employed in Maynard Smith's typology of animal signals. These concepts turn into distinct types of signals, whereas the distinction is based on the relation between form and content or between form and meaning. It appears that the semiotic terminology is basically employed for arguing the motivatedness of the signals. Thus, icon is said to be "a signal whose form is similar to its meaning" (Maynard Smith, Harper 2003: 15) and in icons "the form of the signal is similar to its content" (Maynard Smith, Harper 1995: 309). Indexes or indices are defined as signals whose form "is determined by the content" (ibid.) and "whose intensity is causally related to the quality being signalled" (Maynard Smith, Harper 2003: 15). Symbol is understood as "a signal whose form is unrelated to its meaning" (Maynard Smith, Harper 2003: 15).

Although the use of the concept of "meaning" in this context is a rather remarkable influence of semiotics on evolutionary biology, such interpretation raises some critical questions. For instance, arguing for the similarity between form and content or meaning presupposes their belonging to the same logical category and being comparable, which is far from being self-evident. Discussing arbitrariness in regard to the relations of form and content indicates, however, the influence of Saussurean tradition and the whole trichotomy is probably adapted through the writings of Eco (for example, 1976: 178). Substituting the relationship of sign and its object with that of form and content (or meaning) as done by Maynard Smith can be perhaps explained with the specifics of biological signalling, where the appearance of an animal's body often signals various inner characteristics of the animal. The concepts of content or meaning are also used ambiguously and in a way that is not typical to semiotics, as I will show later. 
The most important alteration in this is, however, that in Peircean semiotics icon, index and symbol are types of signs - not signals and are therefore inseparable from the interpretative activity of the receiver. According to Peirce, "nothing is a sign unless it is interpreted as a sign" (CP 2: 308, my Italics) and sign (or representamen) is "anything which determines something else (its interpretant) to refer to an object" (CP 2: 303, my Italics). This also means that being an icon, index or symbol is rather a quality of a sign and can be related with one and the same physical structure depending on the participating individual and the specific course of the sign process. For instance, the begging display of the female passerine with flapping wings, head and neck bended down and beak opened can be both indexical and iconic. In the short-term perspective, it can be an indexical sign, that is, indicating a physical relation with a meaning something like, "put this caterpillar here, in my mouth". In the longterm perspective, it can be a sign with iconic dominance, signifying the relationship between this specific female and the subsequent feeding behaviour of the chicks.

At the same time it needs to be admitted that the situation is actually also more complex in semiotics and Maynard Smith's unintended criticism points to some essential questions of semiotics as that of the relationship between the sign and the sign vehicle. It is evidently basic intuition in semiotics that signs are relational units that cannot be separated from the activity of the interpreter. At the same time they are not independent from the properties of the physical structures of the world (sign vehicles). This determining relationship is present in some of Charles S. Peirce's many definitions of sign: "I define a Sign as anything which is so determined by something else, called its Object, and so determines an effect [...], which effect I call its Interpretant" (SS 80-81), and it is especially expressed in the concept of "Dynamical Object, which is the Reality which by some means contrives to determine the Sign to its Representation" (CP 4.536). Additionally, Peirce's distinction between icon, index and symbol can 
be understood as an array of signs from the dependence on the object to the dependence on the interpreter's activity. Icon is a sign that "stands for something merely because it resembles it" (EP 1.226), index is a sign "determined by its dynamic object by virtue of being in a real relation to it" (SS 33) whereas symbol is a sign "which fulfills its function regardless of any similarity or analogy with its object and equally regardless of any factual connection therewith, but solely and simply because it will be interpreted to be a representamen" (CP 5.73).

Maynard Smith's perception of icon and index as being more motivated than the symbol thus corresponds in general to Peirce's views. This intuition could also perhaps be a relevant dimension for the contemporary debate over symbolic signs in animals (Deacon 1997: 69-101; Queiroz, Ribeiro 2002). For instance many signals used in courtship such as the tails of the peacock or lyrebird are considered to be symbolic by Maynard Smith exactly on the basis that "form is unrelated to actual fighting ability" (Maynard Smith, Harper 2003: 59). In a similar vein, many developmental processes can also be considered symbolic as for instance regulatory codes that have an arbitrary nature (Maynard Smith 1999: 74). Inducer molecules that could switch any gene on or off are considered symbolic by Maynard Smith, as "there is no necessary connection between their form (chemical composition) and meaning (genes switched on or off)" (Maynard Smith 2000: 185; for discussion, see Godfrey-Smith 2000).

For semiotics, the whole topic can be reformulated as a question of relations between a sign vehicle and a sign, or between a message conveyed in communication and its interpretation by a receiver. In the history of semiotics, the position of classical authors regarding the relation between a physical sign vehicle and a sign in it as interpreted by the receiver is not consistent. If a few classical authors who have expressed their opinion on this topic are arranged from the most objective stance to the most subjective, the following series could be drawn: a) Charles Morris; b) Charles S. Peirce; c) Thomas A. Sebeok; and d) Umberto Eco. In Charles Morris's behaviourist semiotics, a 
sign or preparatory-stimulus is something that "directs behavior with respect to something that is not at the moment a stimulus" (Morris 1971b: 366, my Italics) or "controls behavior towards a goal in a way similar to (but not necessarily identical with) the way something else [...] would control behavior with respect to that goal" (Morris 1971b: 84, my Italics). At the other extreme are the semiological views of Umberto Eco, where a sign is "everything that, on the grounds of a previously established social convention, can be taken as something standing for something else" (Eco 1976: 16, my Italics) and where even icons are not considered to be motivated but mostly conventional (Eco 1976: 191). The positions of Charles S. Peirce and Thomas A. Sebeok rest somewhere in between. With each and every one of those authors, however, the quality of being a sign is dependent upon the specific semiosis, that is, it is not a property of a physical thing. In the words of Charles Morris: "something is a sign only because it is interpreted as a sign of something by some interpreter" (Morris 1971a: 20).

\section{Meanings of signals in evolutionary biology}

As Maynard Smith employs semiotic terminology to describe the relationship between the meaning and form of the signal, it would be clarifying to find out what is considered by those two concepts. Meaning and form have not been explicitly defined, as is also noted in the analysis by Ulrich E. Stegmann (2005: 1016-1017), so assumptions need to be made by observing the context of use. Under the concept of form Maynard Smith appears to describe the general appearance of animal signals, as for instance the ornamentation of male birds (Maynard Smith, Harper 2003: 54), fighting displays in many groups (ibid., 80), nuptial gifts in crickets (ibid., 85) and others. Thus form stands for how animal signals are usually distinguished and described in ethology. Concerning the concept of meaning, indirect confirmation can be found when addressing the question based on the 
discussion above - with what signal form is believed to be in an iconic, indexical or symbolic relation. It appears that meaning in animal communication can be: "fitness" or "some component of" it (Maynard Smith, Harper 2003: 14), "quality of interest to the receiver" (ibid., 33), "heritable foraging ability or health" (Maynard Smith, Harper 2003: 48), "body size and likely fighting ability" (ibid., 50), "relative RHP” (resource holding potential; ibid., 50), "running ability" (ibid., 52), "heritable parasite resistance" (ibid., 54), "ownership" (ibid., 57), "foraging ability" (ibid., 60), "aggression" (ibid., 69), "hunger" (ibid., 110), "good genes" (Maynard Smith, Harper 1995: 309) and "intentions" (Maynard Smith 1982: 4). From this incomplete list it becomes apparent that animal signals in evolutionary biology may mean a variety of things. These meanings also appear to form different categories: some indicating the specific physiological or psychological status of animals (that can probably also be perceived by animals); others indicating some general ability or future potential of an animal; and still others, which are rather theoretical constructs.

When looking for the pairs of signal form and meaning in Maynard Smith's writings, it appears that they are also often accompanied by the specific reference to the receiver (mostly female, but also contestant or predator). Some examples of such constructions are: the "female may choose an index of some component of fitness" (Maynard Smith, Harper 2003: 14); "we describe how female Drosophila subobscura select males according to their ability to 'dance' [...] - a measure of neuromuscular coordination" (Maynard Smith, Harper 2003: 14); "the female has a rule for estimating the quality of a male from his advertisement, $\mathrm{p}=\mathrm{P}(\mathrm{a})$ " (Maynard Smith, Harper 2003: 20); "exposure of the abdomen is a signal of a male's condition, which may be of interest to a female as an indicator of heritable foraging ability or health" (Maynard Smith, Harper 2003: 48). These excerpts indicate that although meaning/form dyads are explicitly described as signals, as it was uncovered before, in actual use the characteristics of the sign process are also included (where according to the definition of Peirce, 
something "stands to somebody for something in some respect or capacity", CP 2:228).

In works of evolutionary biology such game-theoretic constructions are sometimes accompanied with the remark that these should be taken metaphorically (for example, Krebs, Dawkins 1984: 386; the issue is addressed by Krebs and Davies 1997: 11). This makes things even more obscure for a semiotician, as semiosis is a specific triadic relation and there is not much room for metaphors in it. Signals either participate in semiosis or not. If they do, then it should be shown how the signals (representamen) and their possible consequences (interpretant) are present for the animal. In regard to given quotations this would mean demonstrating the relevance of the concepts of "fitness", "neuromuscular coordination", "rule $\mathrm{p}=\mathrm{P}(\mathrm{a})$ for estimating the quality", and "heritable foraging ability or health" for the animal. That would probably require including some form of intentionality or prescience on the cognitive or organismic level of the animal, and on the other hand acknowledging the artificial and combinatory nature of some concepts such as fitness (as discussed in length in for example Mills, Beatty 1979; Ariew, Lewontin 2004). If these signals, however, are not meant to participate in semiosis, then this is not a metaphor but rather camouflage for covering the anthropomorphism or sociomorphic modelling (see Komárek 2003:37-44) present in the theory. After making this critical comment, the sovereignty and integrity of different academic disciplines still need to be admitted; something that is not legitimate from the position of semiotics may work decently within the framework of mathematical models and theoretical constructs of evolutionary biology and vice versa.

A principal difference between semiotics and evolutionary biology is in putting an animate subject into the foreground and considering biological processes from its perspective (cf. Kull et al. 2008: 45-47). Concerning the present topic, this would mean detailed analyses of an animal's subjective world or Umwelt and distinguishing phenomena and processes that can be present for the semiotic self of an animal (in 
the wide Sebeokian sense, including the immunological, cognitive and linguistic self, Sebeok 1991). Evolutionary processes should also be considered from that premise, by distinguishing the processes that an animal can perceive and influence from those that it cannot. Everything in the environment that is present for the animal and passes its organs of perception and subsequent action is subject to its internal representation and interpretational activity. Such a process can be legitimately titled "semiotic selection" (Maran 2005: 171) and sexual selection in most of its expressions is one type thereof. A principal argument for building an understanding of evolution that starts from the individual is the autonomy of the semiotic self as it builds and calibrates itself in self-organising and not a predetermined way in the specific environmental context and developmental history. Thus a semiotic understanding of evolution finds its kinship in biology more in evolutionary developmental biology than in NeoDarwinian synthesis.

\section{Searching for common ground between semiotics and evolutionary biology}

As the conclusion of this article, I would raise a question about the possible dialogue between semiotics and evolutionary biology. Searching for common ground could turn out to be a rather difficult task because of major foundational differences between the two paradigms, and this makes the chance of a conflict arising or losing one's own intellectual sovereignty high. Maynard Smith's approach appears to include at least a possibility to relate semiotics and evolutionary biology in a way that is not antagonistic or subordinating. The positive lesson of his works for semiotics could lie in paying attention to the physical structures and constraints and their influence on the animal communication processes. Introducing indexes or indices as signals that use pre-existing physical restrictions or relations 
to convey meaning is a major innovation that Maynard Smith made later for evolutionary biology. Additionally, in semiotics the role of physical relations or Peircean secondness as a "brute action" for semiotic processes has not received enough attention. From the writings of Thomas A. Sebeok we know that semiosis is the most characteristic trait of life that is common to all life forms (Sebeok 2001:10-12). Jesper Hoffmeyer has added to this the principle of growth of semiotic freedom (understood as the depth of meaning that an individual or species is capable of communicating, Hoffmeyer 2008: 186). The physical space that the biosemiosphere inhabits, relates to and gradually overcomes, has remained, however, a quite unexplored area in semiotics.

In following, I am sketching a few possibilities for how physical processes can relate to and be involved in semiosis. First, semiosis may incorporate Peirce's secondness in order to foresee and avoid this brute force. For instance, a bighorn sheep that uses its senses for searching for safe passage over a mountain cliff employs semiosis to avoid the effect of a physical impact. Cause-effect relations and physical necessities, as for instance the need for food, form a major class of objects of semiosis in the animate world. Additionally, regularities of the living world constantly become bases for the formation of new signs and semiotic structures. According to the maxim by Jesper Hoffmeyer: "Whenever a new habit appears, it tends to become a sign for somebody" (Emmeche, Kull, Stjernfelt 2002: 20). The specifics of this process, and the patterns and limitations in it, are, however, not very well scrutinised in semiotics. Karel Kleisner's concept of semiotic cooption, defined as a situation when the character that was shaped serving a particular role or having a specific meaning within the Umwelt of an organism is coopted by another organism gaining thus a new meaning within its Umwelt, hints at a possible direction (Kleisner 2010). In such a process of sign formation, similarity and categorisation can turn out to be vital mechanisms. 
Second, signs may often be motivated and non-arbitrary because of the existent physical properties or regularities of the world. Here we can think of biological universalities - described on the linguistic level as ontological metaphors by George Lakoff and Mark Johnson (1980: 25-32) - for instance up, growth, full, whole, fresh, symmetry having generally more positive connotations than down, decay, partial, rotten, asymmetry. These relations are built on the general tendencies of organisms participating in natural processes and the behaviour of organic matter. As such, they are quite general but not absolute in nature, as for the meat fly, rotten flesh is just fine. Another example of this kind would derive from the studies of Heini Hediger on spatial relations. Mutually liberating and lasting physical proximity in humans or animals stands for non-aggressiveness and psychological closeness. Grooming behaviour in primates as a sign of attachment has been built on the physical premise that for aggression, close distance is needed.

Third, in some cases there is a specific interrelatedness of semiotic and non-semiotic processes, where things that do not participate in the semiosis become objects in the subsequent semioses. An example of such type can be found in camouflage and mimesis. Differently from most communicative relations of animals, in camouflage and mimesis the specific appearances that do not participate in semiosis prevail for the subsequent generations, whereas those which do participate in semiosis fail. Despite that, the appearances that emerge in such a process of exclusion have a semiotic nature by developing an iconic sign-relation with the object of their imitation (cf. Maran 2007). Another example of a similar kind can be found in the intensity of signals transmitted in communication. The intensity itself, for example, the loudness of the call, may not have any specific meaning for the receiver (although in many cases it is an icon), and in this sense it does not participate in semiosis. At the same time the intensity of the signal is the relevant prerequisite for making semiosis possible and thus it also influences the process of semiotic selection. 
A possibility for the dialogue between semiotics and evolutionary biology could especially be found in the relationship between the physical necessities and effects of semiotic selection, between the motivatedness of signals and unpredictability of semiosis and the influence of all this on the evolution and development of animal communication and sign systems. From semiotics this would require acknowledging the role of physical processes and limitations in semiosis, and from evolutionary biology the introduction of a subjective interpretative perspective. The latter is actually nothing new — in 1993 Tim Guilford and Marian Stamp Dawkins argued that evolutionary biology would benefit from psychological perspective (Guilford, Dawkins 1993). There is unfortunately little such emphasis in the writings of Maynard Smith and his approach to semiotics also remains on the level of naïve interpretation which focuses mainly on adapting terminology. It is also an unfortunate turn of events of scientific development that Maynard Smith approached semiotics through the works of Umberto Eco, who is one of most anthropocentric and culturocentric figures among the classical authors of semiotics. Given the significant differences between the foundations of both paradigms as well as contemporary developments, it is not very likely that the door slightly opened by John Maynard Smith would be used by many researchers in coming years. ${ }^{1}$

This research was supported by the European Union through the European Regional Development Fund (Centre of Excellence CECT) and by Estonian Science Foundation Grant No. 7790. 


\section{References}

Ariew, André; Lewontin, R. C. 2004. The confusions of fitness. The British Journal for the Philosophy of Science 55(2): 347-363.

CP $=$ Peirce, Charles S. 1994. The Collected Papers of Charles Sanders Peirce. [Electronic version (Folio Bound Views); vols. 1-6, Hartshorne, Charles, Weiss, Paul (eds.), 1931-1935; vols. 7-8, Burks, Arthur W. (ed.) 1958.] Cambridge: Harvard University Press. [In-text references are to CP, followed by volume and paragraph numbers]

Deacon, Terrence W. 1997. The Symbolic Species. The Co-Evolution of Language and the Brain. New York, London: W. W. Norton.

Eco, Umberto 1976. A Theory of Semiotics. Bloomington, London: Indiana University Press.

Emmeche, Claus; Kull, Kalevi; Stjernfelt, Frederik 2002. Reading Hoffmeyer, Rethinking Biology. (Tartu Semiotics Library 3.) Tartu: Tartu University Press.

EP $=$ Peirce, Charles Sanders 1992. The Essential Peirce. Selected Philosophical Writings. Vol. 1 (1867-1893). [Houser, Nathan; Kloesel, Christian (eds.)] Bloomington and Indianapolis: Indiana University Press.

Godfrey-Smith, Peter 2000. Information, arbitrariness, and selection: comments on Maynard Smith. Philosophy of Science 67(2): 202-207.

Guilford, Tim; Dawkins, Marian Stamp 1993. Receiver psychology and the design of animal signals. Trends in Neurosciences 16(11): 430-436.

Hoffmeyer, Jesper 2008. Biosemiotics. An Examination into the Signs of Life and the Life of Signs. [Transl. Hoffmeyer, Jesper; Favareau, Donald.] Scranton: Scranton University Press.

Kleisner, Karel 2010. Perceive, co-opt, modify, and live! Towards an understanding of organism as a centre of experience. In: Markoš, Anton (ed.), Biohermeneutics. Biosemiotics 5. Springer: Berlin. Forthcoming.

Komárek, Stanislav 2003. Mimicry, Aposematism and Related Phenomena. Mimetism in Nature and the History of its Study. Muenchen: Lincom Europa.

Krebs, John R.; Davies, Nicholas B. 1993. An Introduction to Behavioural Ecology. [ $3^{\text {rd }}$ ed.] Oxford: Blackwell Scientific.

- 1997. The evolution of behavioural ecology. In: Krebs, John R.; Davies, Nicholas B. (eds.), Behavioural Ecology: An Evolutionary Approach. [4 ${ }^{\text {th }}$ ed.] Oxford: Blackwell Science, 3-12.

Krebs, John R.; Dawkins, Richard 1984. Animal signals: mind-reading and manipulation. In: Krebs, John R.; Davies, Nicholas B. (eds.), Behavioural Ecology: An Evolutionary Approach. [2 ${ }^{\text {nd }}$ ed.] Sunderland: Sinauer, 380-402. 
Kull, Kalevi 1999. Biosemiotics in the twentieth century: a view from biology. Semiotica 127(1/4): 385-414.

- 2004. Uexküll and the post-modern evolutionism. Sign Systems Studies 32(1/2): 99-114.

Kull, Kalevi; Emmeche, Claus; Favareau, Donald 2008. Biosemiotic Questions. Biosemiotics 1: 41-55.

Lakoff, George; Johnson Mark 1980. Metaphors We Live By. Chicago, London: The University of Chicago Press.

Maran, Timo 2005. Mimikri kui kommunikatsioonisemiootiline fenomen. [Mimicry as a communication semiotic phenomenon]. Dissertationes Semioticae Universitatis Tartuensis 7. Tartu: Tartu University Press.

- 2007. Semiotic interpretations of biological mimicry. Semiotica 167(1/4), 223 248.

Marler, Peter 1961. The logical analysis of animal communication. Journal of Theoretical Biology 1: 295-317.

- 1978. Affective and symbolic meaning: Some zoosemiotic speculations. In: Sebeok, Thomas (ed.), Sight, Sound and Sense. Bloomington: Indiana University Press, 113-123.

Maynard Smith, John 1982. Do animals convey information about their intentions? Journal of Theoretical Biology 97(1): 1-5.

- 1995. Genes, memes, \& minds [Daniel C. Dennett. Darwin's Dangerous Idea: Evolution and the Meanings of Life]. The New York Review of Books 42(19): 46-48.

- 1999. The idea of information in biology. The Quarterly Review of Biology 74(4): 395-400.

- 2000. The concept of information in biology. Philosophy of Science 67(2): 177194.

Maynard Smith, John; Harper, David 1995. Animal signals: models and terminology. Journal of Theoretical Biology 177(3), 305-311.

- 2003. Animal Signals. Oxford: Oxford University Press.

Maynard Smith, John; Szathmáry, Erös 2000. The Origins of Life: From the Birth of Life to the Origin of Language. Oxford: Oxford University Press.

Mills, Susan K.; Beatty, John H. 1979. The propensity interpretation of fitness. Philosophy of Science 46(2): 263-286.

Morris, Charles 1971a. Foundations of the theory of signs. In: Morris, Charles. Writings on the General Theory of Signs. The Hague: Mouton, 17-71.

- 1971b. Signs, language, and behavior. In: Morris, Charles. Writings on the General Theory of Signs. The Hague: Mouton, 73-397. 
Nöth, Winfried 2005. Semiotics for biologists. Journal of Biosemiotics 1:195-211.

Queiroz João, Ribeiro, Sidarta 2002. The biological substrate of icons, indexes, and symbols in animal communication: a neurosemiotic analysis of Vervet monkey alarm-calls. In: Shapiro, M., (ed.) The Peirce Seminar Papers 5 - The State of the Art. Oxford: Berghahn Books, 69-78.

Sebeok, Thomas A. 1972. Perspectives in Zoosemiotics. (= Janua Linguarum. Series Minor 122). The Hague: Mouton de Gruyter.

- 1990. Essays in Zoosemiotics (= Monograph Series of the TSC 5). Toronto: Toronto Semiotic Circle; Victoria College in the University of Toronto.

- 1991. The semiotic self. Sign Is Just a Sign. Bloomington, Indianapolis: Indiana University Press, 36-40.

- 1994. Signs: An Introduction to Semiotics. Toronto and Buffalo: University of Toronto Press.

- 2001. Global semiotics. In: Sebeok, Thomas A. Global Semiotics. Bloomington: Indiana University Press, 1-16.

Smith, W. John 1986. An "informational" perspective on manipulation. In: Mitchell, Robert W.; Thompson, Nicholas S. (eds.), Deception. Perspectives on Human and Nonhuman Deceit. New York: State University of New York Press, 71-86.

SS = Peirce, Charles Sanders 1977. Semiotic and Significs: The Correspondence Between Charles S. Peirce and Victoria Lady Welby. [Hardwick, Charles S.; Cook, J. (eds.)] Bloomington: Indiana University Press.

Stegmann, Ulrich E. 2005. John Maynard Smith's notion of animal signals. Philosophy and Biology 20(5): 1011-1025.

Szathmáry, Eörs 2006. Birds as aeroplanes: Remembering John Maynard Smith. Biological Theory 1(1): 84-86.

Weber, Thomas P. 2000. Biological objects, units of selection and character decomposition. Trends in Ecology \& Evolution 15(8): 304-305.

Williams, Nigel 2007. Signs of the times. Current Biology 17(17): R735-R737.

Zahavi, Amotz; Zahavi, Avishag 1997. The Handicap Principle: A Missing Piece of Darwin's Puzzle. Oxford, New York: Oxford University Press. 


\section{Типология сигналов животных Джона Мейнарда Смита с семиотической точки зрения}

Взгляды на коммуникацию животных в семиотике и эволюционной биологии в большинстве своем довольно разные. На этом фоне труды ведущего эволюционного биолога Джона Мейнарда Смита, интересующегося семиотикой, являются интересным исключением и объектом изучения. Данная статья сосредоточивается на использовании и приспособлении семиотической терминологии в трудах Смита, привлекая общие теоретические установки как эволюционной биологии так и семиотики. Развивая типологию сигналов животных, Смит использует понятия икона, индекса и символа для обозначения разных классов сигнала. Он пользуется индексом для обозначения типа сигнала, в котором отношение между качествами и значением сигнала ограничено в силу физических качеств сигнала. Такой подход указывает на проблему мотивированности знака, которая имеет длинную историю в семиотике. В последней части статьи анализируется использование в трудах Мейнарда Смита понятий формы и значения. Оказывается, что в эволюционной биологии сигнал является неопределенным понятием, который может обозначать целую группу явлений: начиная от конкретного физиологического статуса животного до теоретических конструкций. Кроме того, становится ясным, что, используя концепцию сигнала в реальности, зачастую указывают на активность принимающего и процесс интерпретации, что характеризуют скорее знаковой процесс в целом. Положительное влияние работ Смита на семиотику может состоять в обращении внимания на роль физических потребностей в коммуникации животных. Физические ограничения и отношения, до сих пор недостаточно изученные и понятые в семиотике, играют известную роль и в семиотических процессах. 


\section{John Maynard Smithi loomasignaalide tüpoloogia semiootilisest vaatenurgast}

Vaated loomade kommunikatsioonile on semiootikas ja evolutsioonibioloogias olnud enamasti küllalt erinevad. Sellel foonil on semiootikast huvitunud juhtiva evolutsioonibioloogi John Maynard Smithi kirjutised põnevaks erandiks ja uurimisobjektiks. Käesolev artikkel keskendub semiootilise terminoloogia kasutamisele ja kohandamisele Maynard Smithi töödes, kaasates üldiseid teoreetilisi lähtekohti nii semiootikast kui evolutsioonibioloogiast. Arendades loomasignaalide tüpoloogiat, võtab Maynard Smith kasutusele ikooni, indeksi ja sümboli mõisted tähistamaks eri signaaliklasse. Ta kasutab indeksi mõistet tähistamaks signaalitüüpi, milles suhe signaali omaduste ja tähenduse vahel on piiratud signaali füüsiliste omaduste tõttu. Selline lähenemine osutab märkide motiveerituse probleemile, millel on semiootikas pikk ajalugu. Artikli viimases osas analüüsitakse signaali vormi ja tähenduse mõistete kasutust ja sisu Maynard Smithi kirjutistes. Selgub, et evolutsioonibioloogias on signaal ebamäärane mõiste, mis võib tähistada hulka nähtusi looma konkreetsest füsioloogilisest staatusest kuni teoreetiliste konstruktsioonideni. Samuti saab selgeks, et signaali kontseptsiooni tegelikult kasutades viidatakse sageli vastuvõtja aktiivsusele ja interpretatsioonile, mis iseloomustavad pigem märgiprotsessi. Maynard Smithi tööde positiivne mõju semiootikale võiks seisneda tähelepanu pööramises füüsiliste vajaduste rollile loomade kommunikatsioonis. Füüsilised piirangud ja suhted näivad omavad olulist rolli ka semiootilistes protsessides, olgugi et neid pole semiootikas alati piisavalt uuritud või mõistetud. 